\title{
Calcium and bone disease
}

\author{
Harry C. Blair ${ }^{1,{ }^{\star}}$, Lisa J. Robinson ${ }^{1}$, Christopher L.-H. Huang ${ }^{2}$, Li Sun ${ }^{3}$, Peter A. Friedman ${ }^{4}$, \\ Paul H. Schlesinger ${ }^{5}$, and Mone Zaidi ${ }^{3}$ \\ ${ }^{1}$ Departments of Pathology and of Cell Biology and Physiology, University of Pittsburgh and the \\ Veterans airs Health System, Pittsburgh, PA, USA \\ 2Physiological Laboratory, University of Cambridge, Cambridge, UK \\ ${ }^{3}$ The Bone Program, Mount Sinai School of Medicine, New York, NY, USA \\ ${ }^{4}$ Department of Pharmacology and Chemical Biology, University of Pittsburgh School of Medicine, \\ Pittsburgh, PA, USA \\ ${ }^{5}$ Department of Cell Biology and Physiology, Washington University in St. Louis, School of \\ Medicine, St. Louis, MO, USA
}

\section{Abstract}

Calcium transport and calcium signaling are of basic importance in bone cells. Bone is the major store of calcium and a key regulatory organ for calcium homeostasis. Bone, in major part, responds to calcium-dependent signals from the parathyroids and via vitamin D metabolites, although bone retains direct response to extracellular calcium if parathyroid regulation is lost. Improved understanding of calcium transporters and calcium-regulated cellular processes has resulted from analysis of genetic defects, including several defects with low or high bone mass. Osteoblasts deposit calcium by mechanisms including phosphate and calcium transport with alkalinization to absorb acid created by mineral deposition; cartilage calcium mineralization occurs by passive diffusion and phosphate production. Calcium mobilization by osteoclasts is mediated by acid secretion. Both bone forming and bone resorbing cells use calcium signals as regulators of differentiation and activity. This has been studied in more detail in osteoclasts, where both osteoclast differentiation and motility are regulated by calcium.

\section{Keywords}

chondrocalcinosis; cranio-metaphysial dysplasia; hypercalcemia; osteonecrosis; osteoporosis; osteopetrosis

In terrestrial vertebrates, bone contains the vast majority of calcium. Because of this, elaborate mechanisms have evolved to balance calcium homeostasis with maintenance of skeletal strength. We will consider calcium first from the standpoint of mineral transport and then calcium in cell regulation, highlighting inborn errors included that affect the processes. The mass transport of calcium and its balancing anions is carried out by specific active and facilitated transport processes; these are regulated, just as is calcium handling in the kidney and intestine. Bone cells also use calcium to regulate cell differentiation and activity as in other cells, including calcium as a secondary mediator of hormones and cytokines. Calcium is a regulator of cellular attachment, motility and survival in bone degrading osteoclasts.

(C) 2011 International Union of Biochemistry and Molecular Biology, Inc.

*Address for correspondence: Harry C. Blair, University of Pittsburgh, 705 Scaife Hall, Pittsburgh, PA 15261 USA. Tel.: (412) 383-9616; Fax 412-647-8567; hcblair@imap.pitt.edu. 
Key mechanisms that, in turn, modify calcium handling by bone include the parathyroid glands and vitamin D metabolites; these, because they occur outside of the bone, will not be discussed. There are also direct responses of bone cells to extracellular calcium, which function mainly at high calcium activity not reflecting plasma calcium, which will be discussed together with cellular regulation.

\section{Calcium transcytosis and mineral deposition by osteoblasts}

The osteoblast is derived by differentiation of mesenchymal stem cells [1]. Differentiation occurs throughout life when new bone is needed. The osteoblast produces a dense type I collagen matrix with additional accessory proteins including osteocalcin. Osteoblasts function in coordinated groups for bone synthesis and maintenance, which are collectively known as osteons (Fig. 1). The cells within an osteon communicate by gap junctions, and calcium is an important intercellular signal [2]. The type I collagen is very dense and heavily crosslinked, creating an extremely high tensile strength. It comprises $\sim 10 \%$ of the dry mass of bone. Osteocalcin is a calcium-binding $12 \mathrm{kDa}$ protein; its calcium binding depends on post-translational gamma-carboxylation of glutamatic acid, which requires vitamin $\mathrm{K}$. Osteocalcin and other accessory proteins in bone are quantitatively minor and, when deficient, do not affect the physical properties of the bone matrix to a major extent, although there are often effects on bone cell activity. In the case of osteocalcin, its absence promotes bone formation [3].

However, the major component of bone matrix, $90 \%$, is bone mineral. The mineralized matrix is similar to reinforced concrete, with hydroxyapatite mineral providing the resistance to compression, and a vital store of minerals, while dense, aligned, crosslinked collagen provides the tensile strength. Bone mineral is usually considered solely as a calcium store. It does contain almost all of the somatic calcium, but the balancing anions, $\mathrm{PO}_{4}^{3-}$ and $\mathrm{OH}^{-}$, are also important. For example, a chronic acid load will cause skeleton to be resorbed to maintain normal extracellular $\mathrm{pH}$ [4].

Osteoblast mineral deposition is often interpreted as passive precipitation of ions facilitated by crystal nucleation via minor proteins. Although the mineralization is not fully understood, crystal nucleation is, at most, a minor component of a major active transport process. Nonstructural bone proteins can be knocked out without major effects on bone formation: for example, knockout of the calcium-binding protein osteocalcin [3]. Nonstructural bone proteins do have important functions, although noncalcium-based regulation is outside the scope of this discussion. In the main, bone mineral is deposited by regulated transport.

For clarity, we first review the inorganic chemistry of bone and the structural anatomy of the bone forming unit. Bone mineral is, for practical purposes, hydroxyapatite, whose stoichiometry is (with minor variation) $4 \mathrm{Ca}^{2+}: 2 \mathrm{PO}_{4}^{3-}: 2 \mathrm{OH}^{-}$. In solution near neutral $\mathrm{pH}$, its components are $\mathrm{Ca}^{2 \mathrm{p}}$, a mixture of $\mathrm{H}_{2} \mathrm{PO}_{4}^{-}$and $\mathrm{HPO}_{4}^{2-}$, and water. Hydroxyapatite deposition in a closed space requires a continuing supply of calcium, phosphate, and removal of the protons evolved (Fig. 1).

In bone, dense mineral is deposited vectorially in a narrow zone, entirely contained within the organized complex of gap-junction connected osteoblasts [5]. This integrated group of osteoblasts presents a common surface to the extracellular fluid that is sealed by tight junctions [6] and retains connections with earlier generations of osteoblasts, now called osteocytes and embedded in the bone matrix (Fig. 1). The bone matrix is, thus, entirely delimited by cells. The movement of constituent bone proteins and of the ions deposited to produce bone mineral is all regulated by vectorial transport across these cellular membranes. 
Supporting this concept, mineralized matrix is quite stable but if its lining compliment of cells dies it is rapidly degraded [7] as discussed further below. The best demonstration of the function of the osteon and the focal vectorial deposition is that tetracycline and other bonebinding low-MW partially permeable substances accumulate specifically in a narrow mineralizing layer of bone near the surfaces of active osteons, while deeper matrix remains unlabeled $[8,9]$. As clear demonstration both of the osteon structure and that it is isolated by cell membranes from the extracellular fluid, when an osteon dies, such as in osteonecrosis after high-dose glucocorticoid exposure, all cell-matrix surfaces label with hydroxyapatitebinding flours [10]. This occurs by passive adsorption and it is quantitatively much less than accumulation of hydroxyapatite-binding flours during bone formation, although it is shown clearly by laser scanning confocal microscopy [10].

For bulk ion transport during bone formation, calcium transport has been considered in some detail and calcium clearly is transported through the osteoblasts from the extracellular fluid. This transcytosis is regulated [11]. There is insufficient $\mathrm{Ca}^{2 \mathrm{~b}}$-ATPase activity for transport [12]; active transport and accumulation are not needed and would be disruptive to other cell regulation and signaling. Calcium transport via the high affinity calcium-binding cytoplasmic protein calbindin was hypothesized [13], but calbindin-negative cells move calcium at a normal rate [14]. However, osteoblasts express plasma membrane sodiumcalcium exchangers consistent with bulk transport [15], so intracellular calcium storage in a metabolically dormant, bound form still is very likely. Many EF-hand calcium-binding proteins are present in osteoblasts is generally accepted; it is probable that osteoblasts simply have redundant calcium buffering proteins.

The clearest part of osteoblastic support for the mineral deposition is that the cells produce abundant phosphate at the site of mineralization; this system also includes redundant elements. Alkaline phosphatase, expressed as a basolateral ectoenzyme in mineralizing osteoblasts, is essential for normal mineralization, and severe forms of hypophosphatasia are fatal near the time of birth [16]. Pyrophosphate is an important substrate for bone alkaline phosphatase. Supporting enzymes, abundant in osteoblast membranes, include endonucleotide pyrophosphatases, particularly PC-1 [17]; thus, pyrophosphate is, at least in part, from nucleotide triphosphates. Genetic defects due to PC-1 mutations in the bone are not described. ANK (or ANKH), a transmembrane pyrophosphate transporter discovered to cause progressive chondrocalcinosis and fusion of joints (ankylosis), is another source of pyrophosphate $[18,19]$. The details of pyrophosphate generation are not studied; osteoblasts are among the most active protein-synthesizing cells in nature (making vast quantities of type I collagen), and each amino acid addition generates a pyrophosphate, so the source may be simply physiologic intracellular pyrophosphate. Normally, pyrophosphate is degraded in the cell, but ANK may exploit this abundance of intracellular pyrophosphate in the unique situation when large amounts of pyrophosphate are required for matrix mineralization. In humans, mutations in ANK cause cranio-metaphysial dysplasia and chondrocalcinosis [19]. Additional phosphate generating enzymes may, particularly in cartilage, contribute to extracellular phosphate production, including phospho-1, which degrades membrane phosphates including phosphatidyl choline/ethanolamine [20].

An additional ion transport mechanism is required for rapid vectorial deposition of hydroxyapatite: Removal of the acid produced (Fig. 1). This is frequently overlooked but nonetheless essential. The existence of alkalinization of developing bone matrix was initially described as an observation in $\mathrm{pH}$ indicator studies using living bone [21]; these studies also suggested acidification of resorbed surfaces, considered below. Clear evidence of increased $\mathrm{pH}$ at the site of bone formation was obtained in early studies [22], although molecular characterization was not then possible. The process is required to move large quantities of $\mathrm{H}^{\mathrm{p}}$, but the gradient is small, with $\mathrm{pH}$ at the site of mineralization held only $0.4 \mathrm{pH}$ unit 
above the extracellular fluid. Although details are unknown, sodium-hydrogen exchange is a probable key element used to hold $\mathrm{pH}$ at slightly elevated levels to permit vectorial mineral deposition [23]. At present, the mechanism by which $\mathrm{H}^{\mathrm{p}}$ would enter the osteoblastic plasma membrane on the matrix side is completely unknown; possibilities include electrogenic exchange (e.g., $\mathrm{Cl}^{-} / \mathrm{H}^{+}$) or cation exchange (e.g., $\mathrm{K}^{+} / \mathrm{H}^{+}$).

\section{Cartilage versus bone: Advantages of vectorial synthesis}

In contrast to bone, mineralization of cartilage is simple. In mineralizing cartilage, the extracellular matrix is not bounded by cells, it is acellular. In cartilage, large amounts of phosphatases, alkaline phosphatase, and phospho-1 [20] are secreted into the mineralizing zone. These, with a continuous supply of phosphate substrates, will precipitate calcium. In the absence of limitation by cell membranes, acid produced by mineral deposition diffuses away, ultimately to be eliminated by the kidneys, balancing the process. In keeping with this interpretation, calcein is taken up diffusely, and much less strongly, in mineralizing cartilage than in bone.

However, The more complex mechanism of bone synthesis has overwhelming advantages. The density of mineral in cartilage cannot reach levels as high as the (essentially quantitative) mineralization of bone, producing much greater resistance to compression in bone. Further, vectorial deposition of mineral into dense crosslinked, oriented collagen results in vastly higher tensile strength of bone over cartilage.

\section{Calcium-dependent regulation of osteoblast activity}

Osteoblasts and chondrocytes, and their precursors, express the calcium sensing receptor in small amounts. This is the same receptor strongly expressed in the parathyroid where it regulate $\mathrm{PTH}$ production. The calcium sensing receptor and $\mathrm{PTH}$ receptors are seven transmembrane pass G-protein coupled receptors [24,25]. Despite many studies, it is still not clear what is the functional significance of these receptors in bone [26]. Chang et al. [27] approached the problem by deleting the calcium sensing receptor under collagen Ia or collagen II promoters; this produced mice with very poor skeletal growth or fatal prenatal developmental defects. The global knockout [28] has a much less severe developmental phenotype.

How the calcium-sensing receptor deletion is linked to the variable effects is unknown, but a straightforward reconciliation of most elements of this complex literature is not difficult. Other work indicates that PTHrP, an essential developmental signal in many organs, is in part under the control of the calcium sensing receptor and 1 alpha, 25-dihydroxyvitamin D [29]. In the global calcium sensing receptor knockout, partial correction of skeletal response by elevated PTH and 1,25D (not features of collagen-driven calcium-sensing receptor defects [27]) would be expected. Contrariwise, given functional parathyroids and constant serum calcium activity, calcium sensing in the bone would be of no importance (although the receptor might have secondary functions). On the other hand, if the parathyroids do not function normally, the (ancestral) PTHrP system would be unmasked.

However, if the calcium sensor in bone is absent with, thus PTHrP expression in the bone, at least in part, selectively compromised [27], and PTH production by the parathyroid is not elevated to compensate, then PTH receptor-dependent growth plate and osteoblast development [30,31] would be fatally compromised. The absence of calcium-sensing effects in many in vitro cell culture systems may, further, reflect that PTHrP, at least in major part, not a limiting factor in those systems and, consequently, calcium-dependent effects are difficult to demonstrate. These findings are homologous to the roles of ACTH, TSH, and FSH receptors in bone. These additional seven transmembrane-pass G-protein coupled 
receptors are, usually, of minor importance in bone. However, the receptors for these hormones occur in the skeleton, and they cause large changes in cell differentiation and survival when central glycoprotein hormone production varies pathologically [32-34]. The effects on skeletal health can be dramatic [35]. In keeping with this interpretation, inactivating human mutations of the calcium sensing receptor cause hypercalcemia to extents varying with the severity of the defect, but typically without major effects on skeletal development [36].

\section{Calcium pumps and channels in osteoblasts}

Osteoblasts, as essentially all cells, express several calcium channels and maintain cytoplasmic and endosomal calcium concentrations with calcium ATPases, as well as expressing calcium-sodium exchangers mediating bulk calcium transport [37]. The clearest association of calcium channels with regulation of osteoblast function is for L-type voltagesensitive channels [38-41] mediating changes in intracellular calcium that vary with many signals including cell stretch, protein receptors, vitamin D, and PTH. Given the diversity of signaling and that several channels with related activity are present, it is not surprising that inhibitor or knockout studies of L-type calcium channels show variable and partial effects on bone metabolism [42-44]. Nonetheless, the L-type calcium channels are probably the major source of osteoblast intercellular calcium signals [45], which coordinate the activity of cells in the osteon via calcium diffusion through gap junctions (Fig. 1).

Additional calcium channels including transient receptor potential channels may regulate osteoblast proliferation [46]. Further, metabolic coupling to osteoblastic intracellular calcium may involve additional channels including the ryanodine receptor and inositol-1,4,5-trisphosphate receptors (IP3Rs) [47-49]. However, physiological correlates for these additional calcium channels are incompletely characterized. Calcium fluxes in osteoblasts often have anabolic effects but may promote apoptosis, depending on the context. Survival mechanisms triggered by cell stretch can include PI-3-kinase activity and phosphorylation of Akt [50]. On the other hand, increased intracellular calcium via NAD and the RyR induces apoptosis [51]. This is not surprising, in that this type of calcium signal is unrelated, as far as is known, to adhesion-related survival signals. The anabolic/apoptotic decision may also be dependent on the type of calcium channel, and on the magnitude and location of the calcium current.

There are also stretch activated sodium and calcium channels that may mediate effects of shear forces [52], although cation channels secondarily coupled to L-type calcium channels are also known [53]. Stretch-induced calcium transients, probably via L-type calcium channels, are important in the coupling of bone flexion to the activity and proliferation of osteoblasts and related cells [54].

Calcium transport defects undoubtedly cause skeletal abnormalities, but there are few good examples, probably reflecting that many defects are either covered by overlapping function of related channels [42] or are embryonic-lethal defects. In many of the survivable but poorly compensated defects, such as the IP3R1 knockout, there is general runting but effects on osteoblasts are unclear [55].

\section{Calcium mobilization and transport by osteoclasts}

The osteoclast has a vital and unique function, mobilizing massive quantities of calcium from mineralized cartilage or bone by walling off and acidifying the tissue. There may be a slight ability of macrophages to degrade mineralized tissue, related to the survivability, albeit with severe defects, of RANKL (TRANCE) defects where osteoclasts cannot form but where the transport proteins required to make extracellular acid compartments are normal. 
However, at best, mononuclear cells degrade mineral poorly [56]. Dissolving hydroxyapatite at neutral $\mathrm{pH}$ requires adding $\mathrm{H}^{\mathrm{b}}$, the converse of the process in deposition of hydroxyapatite (Fig. 1). For acidification, the osteoclast must isolate a region of the target mineralized tissue and then secrete acid into this space (Fig. 2). The attachment normally is mediated by alphav beta3 integrin (the vitronectin receptor) [59]. Other integrins are also expressed, so that, for example, when the beta3 integrin is absent (Glantzman's thrombasthenia) bone defects are mild or absent [60], although if the protein is present, but defective, severe defects in bone resorption may occur $[61,62]$.

The essential activity that dissolves the calcium salts of bone is acid transport. The osteoclast moves a remarkable amount of acid, $\sim 1.5$ moles of $\mathrm{H}^{+}$per mole of calcium removed at neutral $\mathrm{pH}$ (Fig. 2), and the cell can degrade its volume of mineral in a few hours. In keeping, the cell membrane at the site of acid secretion is expanded and contains very large quantities of acid transporters. The acid transport is dependent on V-type $\mathrm{H}^{+}$ATPase activity [63]. The V-ATPase has membrane $\left(\mathrm{V}_{0}\right)$ and cytoplasmic $\left(\mathrm{V}_{1}\right)$ subassemblies. The membrane assembly consists of a $17 \mathrm{kDa}$ hydrogen channel and a $116 \mathrm{kDa}$ protein with several transmembrane passes which is crucial for membrane insertion. Four homologous genes encode variants of it. The isoform TCIRG1 (ATP6i; A3) is essential for inserting the V-ATPase in the acid-secreting membrane of the osteoclasts, the ruffled border [64]. Defects in TCIRG1 are the most common cause of human osteopetrosis, where mineralized cartilage and bone cannot be degraded [65]. Bone density also varies with heterogeneity in TCIRG1 [66]. Defects in the $\mathrm{V}_{1}$ assembly are typically fatal, because this is essential for many cellular functions. Its structure is homologous to that of the $F_{1}$ subunit of the F-ATPase, which mediates ATP synthesis from proton gradients, whereas the V-ATPase does the opposite; the F-ATPase structure is known in detail. The ATPase assemblies, $\mathrm{F}_{1}$ or $\mathrm{V}_{1}$, are rotary nanomotors that couple ATP hydrolysis and $\mathrm{H}^{\mathrm{b}}$ translocation $[67,68]$. VATPase subunits are among the highest expressed mRNAs in the osteoclast.

The V-ATPase is electrogenic, that is, transporting only $\mathrm{H}^{\mathrm{b}}$, so counter-transport of cations or cotransport of anions must also occur to dissipate the voltage produced by the electrogenic ATPase to permit continuing $\mathrm{H}^{\mathrm{p}}$ translocation. Studies of isolated osteoclast vesicles showed that chloride is required to support the V-ATPase [69]. Two chloride transporters are known to occur in the ruffled border. One is the CLIC5 $\mathrm{Cl}$ channel [70], one of a group of chloride channels usually expressed intracellularly. These occur in other acid compartments, but no human bone disease related to CLIC5 dysfunction is known. The CLIC5 knockout is viable but small; its bone phenotype is not studied. Coexpression of other CLIC genes may moderate the phenotype [71], but further study will be needed to determine whether this is relevant to bone resorption. A second anion transporter involved in osteoclast acid secretion was discovered when mice deficient CLC7 (also called CLCN7 deficient, the gene name), a lysosomal CLC-family chloride-proton antiporter [72], were found to have severe osteopetrosis [73,74]. Curiously, both anion transporters linked with osteoclast cell membrane acid transport otherwise occur in intracellular acidic compartments. The CLC family proteins were once believed to be chloride channels, but their proton exchange activity is definitively established [75,76]. Polymorphisms in CLCN7 are, after TCIRG1 defects, the most common defect in human osteopetrosis [65]. Together, these studies are consistent with a model where $\mathrm{Cl}^{-}$channel activity is essential to establish an $\mathrm{H}^{+}$gradient, while bulk transport is mainly by high-capacity CLCN7 exchange, which cannot run until that gradient exists. In keeping, conversion of CLC7 to a chloride channel by point mutation in mice resulted in a somewhat milder osteopetrosis with lysosomal storage disease similar to that seen in the CLC7 knockout [77].

Another supporting activity required for calcium transport secondary to acid secretion is elimination of base equivalents from the osteoclast. There are two transporters active in this 
role, chloride-bicarbonate exchange and sodium-bicarbonate cotransport [78,79]. The role of sodium-bicarbonate cotransport is uncertain, and one study suggests that it can occur at the acid secreting membrane [80].

Calcium transport out of bone requires that the calcium-rich solution be moved from the osteoclast's attachment to the general extracellular space. To some extent, this may occur when the osteoclast detaches at intervals, in living bone, of about one day, but mineral accumulates in the extracellular fluid much more rapidly. Unlike the osteoblast, a calciumbinding cytoplasmic protein transport mechanism, while possible, would be less likely due to very high calcium activity at the resorption site. Indeed, definitive imaging studies showed that calcium and degraded bone proteins are moved through the cell by vacuolar transcytosis [57,58]. Not surprisingly, osteoclasts also express calcium-binding proteins and an epithelial transient receptor potential-5 voltage-independent calcium channel, TRPV5, that can support significant calcium transport [81]. Although some calcium transcytosis activity might occur by this mechanism, TRPV5 regulates intracellular calcium as part of other regulatory pathways [82]. TRPV5 knockout does not have osteopetrosis but has significant, compensated, calcium transport defects in other sites, particularly calcium uptake in the kidney [83]. TRPV4 is also expressed in osteoclast precursors and may be important in terminal differentiation of osteoclasts under some circumstances, possibly functioning as a calcium-activated calcium channel, although the mechanism is not entirely clear [84]. Other calcium channels frequently implicated in transcellular calcium movement are the sodium-calcium exchangers; the widely expressed NCX1 is found in osteoclasts and may also function in alternative transport mechanisms [85]. Deletion of NTX1 causes fatal cardiac rhythm abnormalities before birth; specific skeletal effects have not been studied in vivo.

\section{Calcium transporters and the calcium sensing receptor in osteoclasts}

Maintenance of cellular and endosomal calcium is critical in most cells, and it is not surprising that in a calcium-handling cell like the osteoclast widely expressed calcium pumps are found [86]. Osteoclasts are sensitive to partial defects in calcium maintenance, and the heterozygotic mouse for SERCA-2 endosomal calcium ATPase had significantly increased bone mineral density [87]. Other cell membrane calcium-transport proteins, implicated mainly in bulk transport, include TRP and NTX, discussed in the previous section, and the (usually endosomal) ryanodine receptor, discussed with endosomal calcium channels below, might under some circumstances function as calcium sensing receptors with calcium response different from the parathyroid-type calcium sensing receptor.

The osteoclast may express the $\mathrm{G}$ protein-coupled $\mathrm{Ca}^{2 \mathrm{p}}$ sensing receptor (CaSR) of the parathyroid gland [88], but this is not widely accepted; issues include that bone cells that may be coisolated with osteoclasts, which do express low levels of the receptor. As far as can be determined, CaSR knockout mice or patients with CaSR defects do not have an osteoclast-related phenotype but have bone changes mainly reflecting mineralization defects [89], consistent with defects in bone differentiation (discussed with osteoblasts, above). On the other hand, osteoclasts definitely respond to very high calcium of 5-20 mM [90], which may involve a number of possible sensor molecules, including as cell membrane calcium transporters, but not the CaSR, which has responsiveness tuned to calcium activity of $\sim 1.5$ $\mathrm{mM}$. The osteoclast-inhibiting effect of several times the physiological extracellular calcium may nevertheless be of functional importance in circumstances where osteoclast-mobilized calcium is not able to diffuse away from the resorption site. 


\section{Endosomal calcium channels regulate osteoclast differentiation and activity}

Transient calcium signals have been noted many times in osteoclasts (e.g., [91] and further studies referenced there), but characterization of the specific calcium channels has been a recent development. Functions in osteoclasts of two classes of functional endosomal channels, ryanodine receptors and inositol trisphosphate receptors (IP3Rs), have been studied.

The physiological mechanism by which the ryanodine receptor functions remains unclear, although abnormal osteoclast differentiation in the knockout mouse establishes that it does play a role in normal osteoclast differentiation [92]. The receptor is usually regarded to be entirely endosomal, but in the osteoclast, RyR2 may also occur on the plasma membrane [93], where it is a strong candidate as an atypical calcium sensor (discussed above). The ryanodine receptor is a calcium-activated calcium release (CRAC) channel, but it is also activated by cyclic ADP ribose, which was shown to activate the receptor in osteoclasts [94]. Thus, the potential physiological pathways by which it mediates effects on osteoclast differentiation may involve a number of possible mechanisms which are, as yet, undefined.

The IP3Rs regulate both osteoclast differentiation and activity. IP3R1 and IP3R2, but not IP3R3, have been shown to occur in osteoclasts $[95,96]$. IP3R2 is active during osteoclast differentiation, and its absence causes a partial defect in osteoclastic differentiation [95]. It is also likely that secondary, CRAC activity is involved in calcium signaling during osteoclastic differentiation, this is discussed in the next section.

IP3R1 is differently regulated, and it is essential for nitric-oxide mediate motility [95]. In differentiated osteoclasts, IP3R1 is the major IP3R form, and it is regulated, interestingly, by a specific isoform of the cyclic GMP-dependent protein kinase, PKG1b by an isoform containing an endosomal recognition motif of of the IP3R-associated cGMP-dependent kinase substrate (IRAG) which includes a binding site specific for PKG1b [97]. Curiously, the role of PKG1b, downstream from the nitric oxide-dependent guanylyl cyclase, is to inactivate the calcium channel, while src-family tyrosine kinase activity initiated by another activation pathway dependent on NO and cGMP activates IP3R2. The components of the src-activating pathway for calcium channel activation are not known. Nitric oxide or activating cGMP analogs disassociated IRAG and IP3R1, and rapid cycling of IRAG-IP3R complexes probably occurs during osteoclast motility. The calcium-regulated proteinase $\mu-$ calpain is an essential component for modification of cell attachment [95,98].

\section{CRAC in osteoclasts}

Marked changes in $\mathrm{Ca}^{2 \mathrm{~b}}$ homeostasis including irregular calcium transients [91] are induced by RANKL-mediated osteoclast differentiation; while most of this activity may be ascribed to endosomal channels. Recently, it was shown that functional activity and expression of the CRAC channel components, Orai1, STIM1 and STIM2 is required to support osteoclast differentiation at normal rates [99]. Either reduced Orail expression or pharmacological inhibitors of CRAC dramatically inhibit osteoclast differentiation. This interesting calcium channel functions through endosomal calcium-sensing EF-hand proteins (STIM) that undergo conformational changes when the endosomal calcium is depleted, for example, by IP3R2, which causes STIM to complex with cell membrane Orai1, creating a calcium channel in complexes of endosomal and plasma membrane proteins called puncta. 


\section{Additional calcium channels in osteoclast regulation}

As in osteoblasts, cell signals involved in differentiation and activity regulation involve additional calcium channels. The transiently active (T-type) voltage gated calcium channel Cav3.2 is implicated in osteoclast differentiation downstream of RANKL under some circumstances [100]. A purine-sensitive membrane receptor calcium channel, P2X7, is a regulator of osteoclast protein kinase $\mathrm{C}$ signaling, and when absent this leads to complex bone changes, which may involve effects on several cell types [101]. There are additional reports indicating that osteoclasts, as most cells, possess additional L-type calcium channels that may regulate cellular activity in some contexts, but, for these, specific pathways are not clear $[102,103]$.

\section{Acknowledgments}

Supported in part by the National Institutes of Health (USA) and by the Department of Veteran's Affairs (USA).

\section{References}

1. Pittenger MF, Mackay AM, Beck SC, Jaiswal RK, Douglas R, Mosca JD, Moorman MA, Simonetti DW, Craig S, Marshak DR. Multilineage potential of adult human mesenchymal stem cells. Science. 1999; 284:143-147. [PubMed: 10102814]

2. Henriksen Z, Hiken JF, Steinberg TH, Jorgensen NR. The predominant mechanism of intercellular calcium wave propagation changes during long-term culture of human osteoblast-like cells. Cell Calcium. 2006; 39:435-444. [PubMed: 16545868]

3. Ducy P, Desbois C, Boyce B, Pinero G, Story B, Dunstan C, Smith E, Bonadio J, Goldstein S, Gundberg C, Bradley A, Karsenty G. Increased bone formation in osteocalcin-deficient mice. Nature. 1996; 382:448-452. [PubMed: 8684484]

4. Barzel US. The effect of excessive acid feeding on bone. Calcif Tissue Res. 1969; 4:94-100. [PubMed: 5363276]

5. Sharrow AC, Li Y, Micsenyi A, Griswold RD, Wells A, Monga SS, Blair HC. Modulation of osteoblast gap junction connectivity by serum, TNFalpha, and TRAIL. Exp Cell Res. 2008; 314:297-308. [PubMed: 18022159]

6. Prêle CM, Horton MA, Caterina P, Stenbeck G. Identification of the molecular mechanisms contributing to polarized trafficking in osteoblasts. Exp Cell Res. 2003; 282:24-34. [PubMed: 12490191]

7. Wang G, Zhang CQ, Sun Y, Feng Y, Chen SB, Cheng XG, Zeng BF. Changes in femoral head blood supply and vascular endothelial growth factor in rabbits with steroid-induced osteonecrosis. J Int Med Res. 2010; 38:1060-1069. [PubMed: 20819443]

8. Frost HM. Measurement of human bone formation by means of tetracycline labelling. Can J Biochem Physiol. 1963; 41:31-42. [PubMed: 13945829]

9. Sedlin ED, Frost HM. Variations in rate of human osteon formation. Can J Biochem Physiol. 1963; 41:19-22. [PubMed: 13987598]

10. Eberhardt AW, Yeager-Jones A, Blair HC. Regional trabecular bone matrix degeneration and osteocyte death in femora of glucocorticoid-treated rabbits. Endocrinology. 2001; 142:1333-1140. [PubMed: 11181552]

11. Short CL, Monk RD, Bushinsky DA, Krieger NS. Hormonal regulation of $\mathrm{Na}^{+}-\mathrm{Ca}^{2+}$ exchange in osteoblast-like cells. J Bone Miner Res. 1994; 9:1159-1166. [PubMed: 7976498]

12. Gay CV, Lloyd QP. Characterization of calcium efflux by osteoblasts derived from long bone periosteum. Comp Biochem Physiol A Physiol. 1995; 111:257-261. [PubMed: 7669110]

13. Balmain N, Berdal A, Hotton D, Cuisinier-Gleizes P, Mathieu H. Calbindin-D9K immunolocalization and vitamin D-dependence in the bone of growing and adult rats. Histochemistry. 1989; 92:359-365. [PubMed: 2511166] 
14. Turnbull CI, Looi K, Mangum JE, Meyer M, Sayer RJ, Hubbard MJ. Calbindin independence of calcium transport in developing teeth contradicts the calcium ferry dogma. J Biol Chem. 2004; 279:55850-55854. [PubMed: 15494408]

15. Stains JP, Weber JA, Gay CV. Expression of $\mathrm{Na}^{+}-\mathrm{Ca}^{2+}$ exchanger isoforms (NCX1 and NCX3) and plasma membrane $\mathrm{Ca}^{2+}$-ATPase during osteoblast differentiation. J Cell Biochem. 2002; 84:625-635. [PubMed: 11813267]

16. Whyte MP. Physiological role of alkaline phosphatase explored in hypophosphatasia. Ann N Y Acad Sci. 2010; 1192:190-200. [PubMed: 20392236]

17. Hatch NE, Li Y, Franceschi RT. FGF2 stimulation of the pyrophosphate-generating enzyme, PC-1, in pre-osteoblast cells is mediated by RUNX2. J Bone Miner Res. 2009; 24:652-662. [PubMed: 19049325]

18. Ho AM, Johnson MD, Kingsley DM. Role of the mouse ank gene in control of tissue calcification and arthritis. Science. 2000; 289:265-270. [PubMed: 10894769]

19. Gurley KA, Reimer RJ, Kingsley DM. Biochemical and genetic analysis of ANK in arthritis and bone disease. Am J Hum Genet. 2006; 79:1017-1029. [PubMed: 17186460]

20. Yadav MC, Simão AM, Narisawa S, Huesa C, McKee MD, Farquharson C, Millán JL. Loss of skeletal mineralization by the simultaneous ablation of PHOSPHO1 and alkaline phosphatase function-a unified model of the mechanisms of initiation of skeletal calcification. J Bone Miner Res. 2010 in press.

21. Cretin A. Contribution histochimique a l'étude de la construction et de la destruction osseuse. La Presse Medicale. 1951; 59:1240-1242. [PubMed: 14875726]

22. Schartum S, Nichols G Jr. Concerning pH gradients between the extracellular compartment and fluids bathing the bone mineral surface and their relation to calcium ion distribution. J Clin Invest. 1962; 41:1163-1168. [PubMed: 14498063]

23. Redhead CR. Ionic regulation of intracellular $\mathrm{pH}$ in rat calvarial osteoblasts. J Physiol. 1988; 401:455-468. [PubMed: 2845064]

24. Huang C, Miller RT. The calcium-sensing receptor and its interacting proteins. J Cell Mol Med. 2007; 11:923-934. [PubMed: 17979874]

25. Gensure RC, Gardella TJ, Jüppner H. Parathyroid hormone and parathyroid hormone-related peptide, and their receptors. Biochem Biophys Res Commun. 2005; 328:666-678. [PubMed: 15694400]

26. Theman TA, Collins MT. The role of the calcium-sensing receptor in bone biology and pathophysiology. Curr Pharm Biotechnol. 2009; 10:289-301. [PubMed: 19355939]

27. Chang W, Tu C, Chen TH, Bikle D, Shoback D. The extracellular calcium-sensing receptor (CaSR) is a critical modulator of skeletal development. Sci Signal. 2008; 1:ra1. [PubMed: 18765830]

28. Ho C, Conner DA, Pollak MR, Ladd DJ, Kifor O, Warren HB, Brown EM, Seidman JG, Seidman CE. A mouse model of human familial hypocalciuric hypercalcemia and neonatal severe hyperparathyroidism. Nat Genet. 1995; 11:389-394. [PubMed: 7493018]

29. Sun W, Sun W, Liu J, Zhou X, Xiao Y, Karaplis A, Pollak MR, Brown E, Goltzman D, Miao D. Alterations in phosphorus, calcium and PTHrP contribute to defects in dental and dental alveolar bone formation in calcium-sensing receptor-deficient mice. Development. 2010; 137:985-992. [PubMed: 20150282]

30. Broadus AE, Macica C, Chen X. The PTHrP functional domain is at the gates of endochondral bones. Ann N Y Acad Sci. 2007; 1116:65-81. [PubMed: 18083922]

31. Kronenberg HM. PTHrP and skeletal development. Ann N Y Acad Sci. 2006; 1068:1-13. [PubMed: 16831900]

32. Zaidi M, Sun L, Robinson LJ, Tourkova IL, Liu L, Wang Y, Zhu LL, Liu X, Li J, Peng Y, Yang G, Shi X, Levine A, Iqbal J, Yaroslavskiy BB, Isales C, Blair HC. ACTH protects against glucocorticoid-induced osteonecrosis of bone. Proc Natl Acad Sci USA. 2010; 107:8782-8787. [PubMed: 20421485]

33. Robinson LJ, Tourkova I, Wang Y, Sharrow AC, Landau MS, Yaroslavskiy BB, Sun L, Zaidi M, Blair HC. FSH-receptor isoforms and FSH-dependent gene transcription in human monocytes and osteoclasts. Biochem Biophys Res Commun. 2010; 394:12-17. [PubMed: 20171950] 
34. Abe E, Marians RC, Yu W, Wu XB, Ando T, Li Y, Iqbal J, Eldeiry L, Rajendren G, Blair HC, Davies TF, Zaidi M. TSH is a negative regulator of skeletal remodeling. Cell. 2003; 115:151-162. [PubMed: 14567913]

35. Blair HC, Wells A, Isales CM. Pituitary glycoprotein hormone receptors in non-endocrine organs. Trends Endocrinol Metab. 2007; 18:227-233. [PubMed: 17588768]

36. Brown EM. The calcium-sensing receptor: physiology, pathophysiology and CaR-based therapeutics. Subcell Biochem. 2007; 45:139-167. [PubMed: 18193637]

37. Sosnoski DM, Gay CV. NCX3 is a major functional isoform of the sodium-calcium exchanger in osteoblasts. J Cell Biochem. 2008; 103:1101-1110. [PubMed: 17668452]

38. Liu D, Genetos DC, Shao Y, Geist DJ, Li J, Ke HZ, Turner CH, Duncan RL. Activation of extracellular-signal regulated kinase (ERK1/2) by fluid shear is $\mathrm{Ca}^{2+}$ - and ATP-dependent in MC3T3-E1 osteoblasts. Bone. 2008; 42:644-652. [PubMed: 18291742]

39. Shin MK, Kim MK, Bae YS, Jo I, Lee SJ, Chung CP, Park YJ, Min do S. A novel collagenbinding peptide promotes osteogenic differentiation via $\mathrm{Ca}^{2+} /$ calmodulin-dependent protein kinase II/ERK/AP-1 signaling pathway in human bone marrow-derived mesenchymal stem cells. Cell Signal. 2008; 20:613-624. [PubMed: 18248957]

40. Gu Y, Preston MR, Magnay J, El Haj AJ, Publicover SJ. Hormonally-regulated expression of voltage-operated $\mathrm{Ca}^{2+}$ channels in osteocytic (MLO-Y4) cells. Biochem Biophys Res Commun. 2001; 282:536-542. [PubMed: 11401493]

41. Bergh JJ, Shao Y, Puente E, Duncan RL, Farach-Carson MC. Osteoblast $\mathrm{Ca}^{2+}$ permeability and voltage-sensitive $\mathrm{Ca}^{2+}$ channel expression is temporally regulated by 1,25 -dihydroxyvitamin $\mathrm{D}_{3}$. Am J Physiol Cell Physiol. 2006; 290:C822- C831. [PubMed: 16221734]

42. Li J, Zhao L, Ferries IK, Jiang L, Desta MZ, Yu X, Yang Z, Duncan RL, Turner CH. Skeletal phenotype of mice with a null mutation in Cav 1.3 L-type calcium channel. J Musculoskelet Neuronal Interact. 2010; 10:180-187. [PubMed: 20516636]

43. Zahanich I, Graf EM, Heubach JF, Hempel U, Boxberger S, Ravens U. Molecular and functional expression of voltage-operated calcium channels during osteogenic differentiation of human mesenchymal stem cells. J Bone Miner Res. 2005; 20:1637-1646. [PubMed: 16059635]

44. Nishiya Y, Kosaka N, Uchii M, Sugimoto S. A potent 1,4-dihydropyridine L-type calcium channel blocker, benidipine, promotes osteoblast differentiation. Calcif Tissue Int. 2002; 70:30-39. [PubMed: 11907705]

45. Jorgensen NR, Teilmann SC, Henriksen Z, Civitelli R, Sorensen OH, Steinberg TH. Activation of L-type calcium channels is required for gap junction-mediated intercellular calcium signaling in osteoblastic cells. J Biol Chem. 2003; 278:4082-4086. [PubMed: 12446698]

46. Labelle D, Jumarie C, Moreau R. Capacitative calcium entry and proliferation of human osteoblast-like MG-63 cells. Cell Prolif. 2007; 40:866-884. [PubMed: 18021176]

47. Sun L, Adebanjo OA, Koval A, Anandatheerthavarada HK, Iqbal J, Wu XY, Moonga BS, Wu XB, Biswas G, Bevis PJ, Kumegawa M, Epstein S, Huang CL, Avadhani NG, Abe E, Zaidi M. A novel mechanism for coupling cellular intermediary metabolism to cytosolic $\mathrm{Ca}^{2+}$ signaling via CD38/ ADP-ribosyl cyclase, a putative intracellular NAD ${ }^{+}$sensor. FASEB J. 2002; 16:302-314. [PubMed: 11874980]

48. Kirkwood KL, Homick K, Dragon MB, Bradford PG. Cloning and characterization of the type I inositol 1,4,5-trisphosphate receptor gene promoter. Regulation by 17 beta-estradiol in osteoblasts. J Biol Chem. 1997; 272:22425-22431. [PubMed: 9278393]

49. Bradford PG, Maglich JM, Kirkwood KL. IL-1beta increases type 1 inositol trisphosphate receptor expression and IL-6 secretory capacity in osteoblastic cell cultures. Mol Cell Biol Res Commun. 2000; 3:73-75. [PubMed: 10775502]

50. Danciu TE, Adam RM, Naruse K, Freeman MR, Hauschka PV. Calcium regulates the PI3K-Akt pathway in stretched osteoblasts. FEBS Lett. 2003; 536:193-197. [PubMed: 12586362]

51. Romanello M, Padoan M, Franco L, Veronesi V, Moro L, D’Andrea P. Extracellular NAD ${ }^{+}$ induces calcium signaling and apoptosis in human osteoblastic cells. Biochem Biophys Res Commun. 2001; 285:1226-1231. [PubMed: 11478787] 
52. Kizer N, Guo XL, Hruska K. Reconstitution of stretch-activated cation channels by expression of the alpha-subunit of the epithelial sodium channel cloned from osteoblasts. Proc Natl Acad Sci USA. 1997; 94:1013-1018. [PubMed: 9023374]

53. Hughes S, Magnay J, Foreman M, Publicover SJ, Dobson JP, El Haj AJ. Expression of the mechanosensitive $2 \mathrm{PK}^{+}$channel TREK-1 in human osteoblasts. J Cell Physiol. 2006; 206:738748. [PubMed: 16250016]

54. Hughes-Fulford M. Signal transduction and mechanical stress. Sci STKE. 2004; 2004:RE12. [PubMed: 15353762]

55. Hirota J, Baba M, Matsumoto M, Furuichi T, Takatsu K, Mikoshiba K. T-cell-receptor signalling in inositol-1,4,5-trisphosphate receptor (IP3R) type-1-deficient mice: is IP3R type 1 essential for T-cell-receptor signalling? Biochem J. 1998; 333:615-619. [PubMed: 9677320]

56. Blair HC, Athanasou NA. Recent advances in osteoclast biology and pathological bone resorption. Histol Histopathol. 2004; 19:189-199. [PubMed: 14702187]

57. Nesbitt SA, Horton MA. Trafficking of matrix collagens through bone-resorbing osteoclasts. Science. 1997; 276:266-269. [PubMed: 9092478]

58. Salo J, Lehenkari P, Metsikko K, Vanananen HK. Removal of osteoclast bone resorption products by transcytosis. Science. 1997; 276:270-273. [PubMed: 9092479]

59. Miyauchi A, Alvarez J, Greenfield EM, Teti A, Grano M, Colucci S, Zambonin-Zallone A, Ross FP, Teitelbaum SL, Cheresh D. Recognition of osteopontin and related peptides by an alpha v beta 3 integrin stimulates immediate cell signals in osteoclasts. J Biol Chem. 1991; 266:20369-20374. [PubMed: 1939092]

60. Horton MA, Massey HM, Rosenberg N, Nicholls B, Seligsohn U, Flanagan AM. Upregulation of osteoclast alpha2beta1 integrin compensates for lack of alphavbeta3 vitronectin receptor in IraqiJewish-type Glanzmann thrombasthenia. Br J Haematol. 2003; 122:950-957. [PubMed: 12956766]

61. Yarali N, Fişgin T, Duru F, Kara A. Osteopetrosis and Glanzmann's thrombasthenia in a child. Ann Hematol. 2003; 82:254-256. [PubMed: 12707732]

62. Feng X, Novack DV, Faccio R, Ory DS, Aya K, Boyer MI, McHugh KP, Ross FP, Teitelbaum SL. A Glanzmann's mutation in beta 3 integrin specifically impairs osteoclast function. J Clin Invest. 2001; 107:1137-1144. [PubMed: 11342577]

63. Blair HC, Teitelbaum SL, Ghiselli R, Gluck S. Osteoclastic bone resorption by a polarized vacuolar proton pump. Science. 1989; 245:855-857. [PubMed: 2528207]

64. Li YP, Chen W, Liang Y, Li E, Stashenko P. Atp6i-deficient mice exhibit severe osteopetrosis due to loss of osteoclast-mediated extracellular acidification. Nat Genet. 1999; 23:447-451. [PubMed: 10581033]

65. Blair HC, Borysenko CW, Villa A, Schlesinger PH, Kalla SE, Yaroslavskiy BB, Garcia-Palacios V, Oakley JI, Orchard PJ. In vitro differentiation of CD14 cells from osteopetrotic subjects: contrasting phenotypes with TCIRG1, CLCN7, and attachment defects. J Bone Miner Res. 2004; 19:1329-1338. [PubMed: 15231021]

66. Carn G, Koller DL, Peacock M, Hui SL, Evans WE, Conneally PM, Johnston CC Jr, Foroud T, Econs MJ. Sibling pair linkage and association studies between peak bone mineral density and the gene locus for the osteoclast-specific subunit (OC116) of the vacuolar proton pump on chromosome 11p12-13. J Clin Endocrinol Metab. 2002; 87:3819-3824. [PubMed: 12161516]

67. Boyer PD. The ATP synthase-a splendid molecular machine. Annu Rev Biochem. 1997; 66:717749. [PubMed: 9242922]

68. Finbow ME, Harrison MA. The vacuolar $\mathrm{H}^{+}$-ATPase: a universal proton pump of eukaryotes. Biochem J. 1997; 324:697-712. [PubMed: 9210392]

69. Blair HC, Teitelbaum SL, Tan HL, Koziol CM, Schlesinger PH. Passive chloride permeability charge coupled to $\mathrm{H}^{+}$-ATPase of avian osteoclast ruffled membrane. Am J Physiol. 1991; 260:C1315- C1324. [PubMed: 1829326]

70. Schlesinger PH, Blair HC, Teitelbaum SL, Edwards JC. Characterization of the osteoclast ruffled border chloride channel and its role in bone resorption. J Biol Chem. 1997; 272:18636-18643. [PubMed: 9228032] 
71. Bradford EM, Miller ML, Prasad V, Nieman ML, Gawenis LR, Berryman M, Lorenz JN, Tso P, Shull GE. CLIC5 mutant mice are resistant to diet-induced obesity and exhibit gastric hemorrhaging and increased susceptibility to torpor. Am J Physiol. 2010; 298:R1531-R1542.

72. Brandt S, Jentsch TJ. ClC-6 and ClC-7 are two novel broadly expressed members of the CLC chloride channel family. FEBS Lett. 1995; 377:15-20. [PubMed: 8543009]

73. Cleiren E, Benichou O, Van Hul E, Gram J, Bollerslev J, Singer FR, Beaverson K, Aledo A, Whyte MP, Yoneyama T, deVernejoul MC, Van Hul W. Albers-Schonberg disease (autosomal dominant osteopetrosis, type II) results from mutations in the ClCN7 chloride channel gene. Hum Mol Genet. 2001; 10:2861-2867. [PubMed: 11741829]

74. Kornak U, Kasper D, Bosl MR, Kaiser E, Schweizer M, Schulz A, Friedrich W, Delling G, Jentsch TJ. Loss of the ClC-7 chloride channel leads to osteopetrosis in mice and man. Cell. 2001; 104:205-215. [PubMed: 11207362]

75. Diewald L, Rupp J, Dreger M, Hucho F, Gillen C, Nawrath H. Activation by acidic pH of CLC-7 expressed in oocytes from Xenopus laevis. Biochem Biophys Res Commun. 2002; 291:421-424. [PubMed: 11846422]

76. Scheel O, Zdebik AA, Lourdel S, Jentsch TJ. Voltage-dependent electrogenic chloride/proton exchange by endosomal CLC proteins. Nature. 2005; 436:424-427. [PubMed: 16034422]

77. Weinert S, Jabs S, Supanchart C, Schweizer M, Gimber N, Richter M, Rademann J, Stauber T, Kornak U, Jentsch TJ. Lysosomal pathology and osteopetrosis upon loss of $\mathrm{H}^{+}$-driven lysosomal $\mathrm{Cl}^{-}$accumulation. Science. 2010; 328:1401-1403. [PubMed: 20430974]

78. Teti A, Blair HC, Teitelbaum SL, Kahn AJ, Koziol C, Konsek J, Zambonin-Zallone A, Schlesinger $\mathrm{PH}$. Cytoplasmic $\mathrm{pH}$ regulation and chloride/bicarbonate exchange in avian osteoclasts. J Clin Invest. 1989; 83:227-233. [PubMed: 2910910]

79. Bouyer P, Sakai H, Itokawa T, Kawano T, Fulton CM, Boron WF, Insogna KL. Colonystimulating factor-1 increases osteoclast intracellular $\mathrm{pH}$ and promotes survival via the electroneutral Na/HCO3 cotransporter NBCn1. Endocrinology. 2007; 148:831-840. [PubMed: 17068143]

80. Riihonen R, Nielsen S, Väänänen HK, Laitala-Leinonen T, Kwon TH. Degradation of hydroxyapatite in vivo and in vitro requires osteoclastic sodium-bicarbonate co-transporter NBCn1. Matrix Biol. 2010; 29:287-294. [PubMed: 20079835]

81. van der Eerden BC, Hoenderop JG, de Vries TJ, Schoenmaker T, Buurman CJ, Uitterlinden AG, Pols HA, Bindels RJ, van Leeuwen JP. The epithelial $\mathrm{Ca}^{2+}$-ATPase channel TRPV5 is essential for proper osteoclastic bone resorption. Proc Natl Acad Sci USA. 2005; 102:17507-17512. [PubMed: 16291808]

82. Chamoux E, Bisson M, Payet MD, Roux S. TRPV-5 mediates a receptor activator of NF-kappaB (RANK) ligand-induced increase in cytosolic $\mathrm{Ca}^{2+}$-ATPase in human osteoclasts and downregulates bone resorption. J Biol Chem. 2010; 285:25354-25362. [PubMed: 20547482]

83. Renkema KY, Nijenhuis T, van der Eerden BC, van der Kemp AW, Weinans H, van Leeuwen JP, Bindels RJ, Hoenderop JG. Hypervitaminosis D mediates compensatory $\mathrm{Ca}^{2+}$-ATPase hyperabsorption in TRPV5 knockout mice. J Am Soc Nephrol. 2005; 16:3188-3195. [PubMed: 16148038]

84. Masuyama R, Vriens J, Voets T, Karashima Y, Owsianik G, Vennekens R, Lieben L, Torrekens S, Moermans K, Vanden Bosch A, Bouillon R, Nilius B, Carmeliet G. TRPV4-mediated calcium influx regulates terminal differentiation of osteoclasts. Cell Metab. 2008; 8:257-265. [PubMed: 18762026]

85. Moonga BS, Davidson R, Sun L, Adebanjo OA, Moser J, Abedin M, Zaidi N, Huang CL, Zaidi M. Identification and characterization of a sodium/calcium exchanger, NCX-1, in osteoclasts and its role in bone resorption. Biochem Biophys Res Commun. 2001; 283:770-775. [PubMed: 11350050]

86. Bekker PJ, Gay CV. Characterization of a $\mathrm{Ca}^{2+}$-ATPase in osteoclast plasma membrane. J Bone Miner Res. 1990; 5:557-567. [PubMed: 2143347]

87. Yang YM, Kim MS, Son A, Hong JH, Kim KH, Seo JT, Lee SI, Shin DM. Alteration of RANKLinduced osteoclastogenesis in primary cultured osteoclasts from CSERCA2 ${ }^{+/-}$-ATPase mice. J Bone Miner Res. 2009; 24:1763-1769. [PubMed: 19419309] 
88. Kameda T, Mano H, Yamada Y, Takai H, Amizuka N, Kobori M, Izumi N, Kawashima H, Ozawa H, Ikeda K, Kameda A, Hakeda Y, Kumegawa M. Calcium-sensing receptor in mature osteoclasts, which are bone resorbing cells. Biochem Biophys Res Commun. 1998; 245:419-422. [PubMed: 9571166]

89. Garner SC, Pi M, Tu Q, Quarles LD. Rickets in cation-sensing receptor-deficient mice: an unexpected skeletal phenotype. Endocrinology. 2001; 142:3996-4005. [PubMed: 11517179]

90. Zaidi M, Kerby J, Huang CL, Alam T, Rathod H, Chambers TJ, Moonga BS. Divalent cations mimic the inhibitory effect of extracellular ionised calcium on bone resorption by isolated rat osteoclasts: further evidence for a "calcium receptor". J Cell Physiol. 1991; 149:422-427. [PubMed: 1660481]

91. Radding W, Jordan SE, Hester RB, Blair HC. Intracellular calcium puffs in osteoclasts. Exp Cell Res. 1999; 253:689-696. [PubMed: 10585292]

92. Sun L, Iqbal J, Dolgilevich S, Yuen T, Wu XB, Moonga BS, Adebanjo OA, Bevis PJ, Lund F, Huang CL, Blair HC, Abe E, Zaidi M. Disordered osteoclast formation and function in a CD38 (ADP-ribosyl cyclase)-deficient mouse establishes an essential role for CD38 in bone resorption. FASEB J. 2003; 17:369-375. [PubMed: 12631576]

93. Moonga BS, Li S, Iqbal J, Davidson R, Shankar VS, Bevis PJ, Inzerillo A, Abe E, Huang CL, Zaidi M. $\mathrm{Ca}^{2+}$-ATPase influx through the osteoclastic plasma membrane ryanodine receptor. Am J Physiol Renal Physiol. 2002; 282:F921-F932. [PubMed: 11934703]

94. Sun L, Adebanjo OA, Moonga BS, Corisdeo S, Anandatheerthavarada HK, Biswas G, Arakawa T, Hakeda Y, Koval A, Sodam B, Bevis PJ, Moser AJ, Lai FA, Epstein S, Troen BR, Kumegawa M, Zaidi M. CD38/ADP-ribosyl cyclase: a new role in the regulation of osteoclastic bone resorption. J Cell Biol. 1999; 146:1161-1172. [PubMed: 10477767]

95. Yaroslavskiy BB, Sharrow AC, Wells A, Robinson LJ, Blair HC. Necessity of inositol $(1,4,5)-$ trisphosphate receptor 1 and $\mu$-calpain in NO-induced osteoclast motility. J Cell Sci. 2007; 120:2884-2894. [PubMed: 17690304]

96. Kuroda Y, Hisatsune C, Nakamura T, Matsuo K, Mikoshiba K. Osteoblasts induce $\mathrm{Ca}^{2+}$-ATPase oscillation-independent NFATc1 activation during osteoclastogenesis. Proc Natl Acad Sci USA. 2008; 105:8643-8648. [PubMed: 18552177]

97. Yaroslavskiy BB, Turkova I, Wang Y, Robinson LJ, Blair HC. Functional osteoclast attachment requires inositol-1,4,5-trisphosphate receptor-associated cGMP-dependent kinase substrate. Lab Invest. 2010; 90:1533-1542. [PubMed: 20567233]

98. Marzia M, Chiusaroli R, Neff L, Kim NY, Chishti AH, Baron R, Horne WC. Calpain is required for normal osteoclast function and is down-regulated by calcitonin. J Biol Chem. 2006; 281:97459754. [PubMed: 16461769]

99. Zhou Y, Lewis TL, Robinson LJ, Brundage KM, Schafer R, Martin KH, Blair HC, Soboloff J, Barnett JB. The role of calcium release activated calcium channels in osteoclast differentiation. J Cell Physiol. 2010; 226:1082-1089. [PubMed: 20839232]

100. Koide M, Kinugawa S, Ninomiya T, Mizoguchi T, Yamashita T, Maeda K, Yasuda H, Kobayashi Y, Nakamura H, Takahashi N, Udagawa N. Diphenylhydantoin inhibits osteoclast differentiation and function through suppression of NFATc1 signaling. J Bone Miner Res. 2009; 24:1469-1480. [PubMed: 19292614]

101. Armstrong S, Pereverzev A, Dixon SJ, Sims SM. Activation of P2X7 receptors causes isoformspecific translocation of protein kinase C in osteoclasts. J Cell Sci. 2009; 122:136-144. [PubMed: 19066285]

102. Ritchie CK, Maercklein PB, Fitzpatrick LA. Direct effect of calcium channel antagonists on osteoclast function: alterations in bone resorption and intracellular calcium concentrations. Endocrinology. 1994; 135:996-1003. [PubMed: 8070395]

103. Teti A, Grano M, Colucci S, Argentino L, Barattolo R, Miyauchi A, Teitelbaum SL, Hruska KA, Zambonin Zallone A. Voltage dependent calcium channel expression in isolated osteoclasts. Boll Soc Ital Biol Sper. 1989; 65:1115-1118. [PubMed: 2560636] 


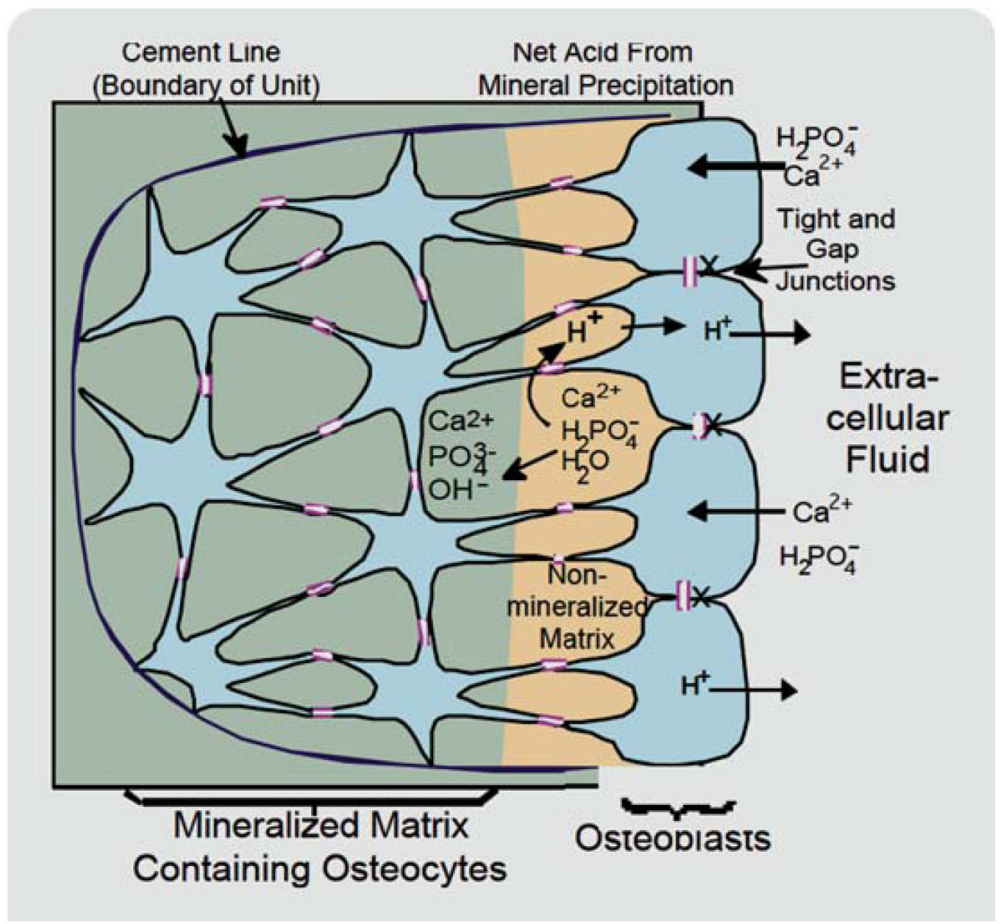

Fig. 1.

The osteon and vectorial transport of mineral. The bone forming unit, or osteon, is comprised of surface cells (osteoblasts) and cells buried in matrix (osteocytes), all connected by gap junctions and separated from the extracellular fluid by tight junctions. Bone mineral is accumulated by active formation of phosphate and passive calcium transport, with an alkaline $\mathrm{pH}$ maintained to allow the mineral to precipitate despite the evolution of $\mathrm{H}^{1}$, which is required by the stoichiometry (see text). [Color figure can be viewed in the online issue, which is available at wileyonlinelibrary.com.] 


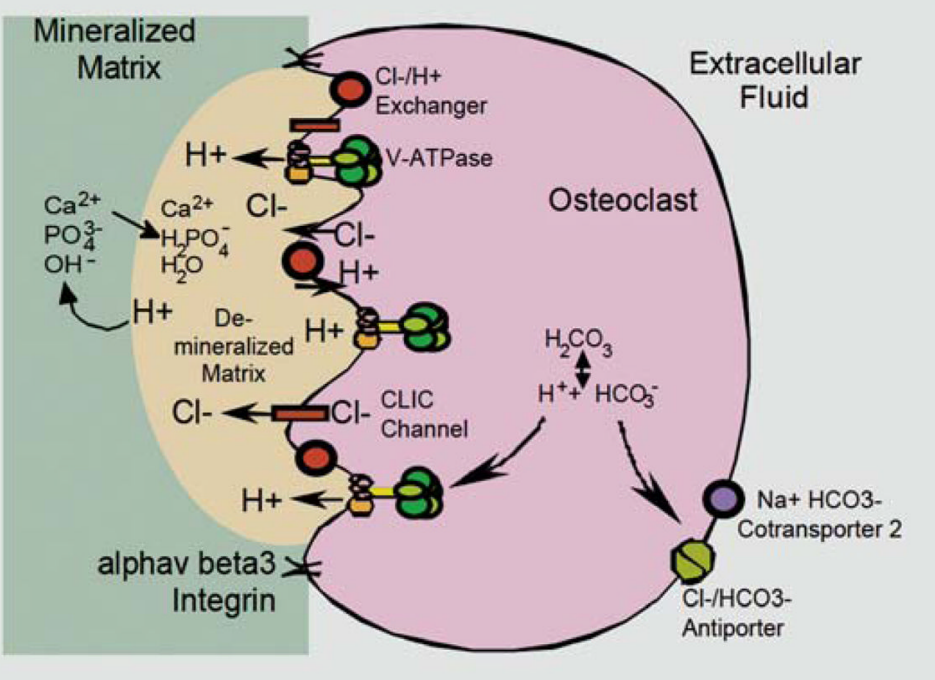

Fig. 2.

Transport processes in the osteoclast that mediate calcium mobilization. The osteoclast is a multinucleated cell that attaches to mineralized tissues by close association of cell membrane using an alphav beta3 integrin ring. Within the compartment thus produced, the cell expresses a specialized organelle, the ruffled border, in which large quantities of vacuolar-(V) type H1-ATPase are inserted. A special membrane component of the VATPase is essential for this distribution. In addition, at least two further transporters, a chloride channel and a chloride proton exchanger, occur and dissipate the voltage gradient produced by the V-ATPase, which is electrogenic (that is, transports H1 without a balancing ion). Cellular $\mathrm{pH}$ is maintained by bicarbonate transporters at the basolateral surfaces of the cell. Calcium liberated by acidification is moved through the cell by vacuolar transcytosis $[57,58]$. [Color figure can be viewed in the online issue, which is available at wileyonlinelibrary.com.] 